\title{
Anticancer and Antioxidant Activities of Some Algae from Western Libyan Coast
}

\author{
Rabia Alghazeer ${ }^{a}$, Mahboba Nailia ${ }^{a}$ Nazlin K. Howell ${ }^{b}$ \\ a: Chemistry Department, Faculty of Sciences, University of Tripoli, Tripoli, Libya \\ b: Faculty of Health and Medical Sciences, University of Surrey, Guildford, Surrey, \\ United Kingdom GU2 7XH \\ Corresponding Author: rabia_alghazeer@yahoo.com
}

\begin{abstract}
Seaweeds are considered as one of the largest biomass producers in marine environment that is rich in bioactive metabolites and a source of natural ingredients for functional foods. The potential antioxidant activity and the potential inhibition of Caco2 cell proliferation, of crude extracts of: Chlorophyta (Ulva lactuca, and Codium tomentosum), Phaeophyta (Cystoseira crinita, Cystoseira stricta, and Sargassum vulgare), and Rhodophyta (Gelidium latifolium, Hypnea musciformis, and Jania rubens) collected from western Libyan coast were evaluated in vitro. The antioxidant activity was determined by reducing power and DPPH assays while cell proliferation, morphological changes and the cell cycle arrest were assessed by MTT, inverted light microscope and flow cytometry methods respectively. The polyphenols and flavonoids rich extracts showed remarkable reducing power and antiradical properties. After exposure of $\mathrm{Caco} 2$ cells to; various concentrations of extracts (50, 100,150 and $200 \mu \mathrm{g} / \mathrm{mL}$ ) especially from brown algae for $72 \mathrm{~h}$, significantly reduced cell proliferation. The antiproliferative effect of algae extracts was correlated with their polyphenol and flavonoid contents. Cell cycle analysis further showed that cells were arrested in $\mathrm{G}$ phases along with an increment in sub-diploidal cell population (sub-G) after extract application. These results imply that seaweeds which are rich in bioactive compounds may be in anticancer drug research programs. However, further investigations are essential to reveal the molecular mechanisms of the anticancer activities of these algae.
\end{abstract}

Keywords: polyphenols, flavonoids, seaweeds, antioxidant activity, anticancer activity 


\section{Introduction}

Seaweeds are large and diverse groups of that are rich in active metabolites and a source of novel ingredients for functional foods. Nutritional studies on seaweeds indicate that brown, green and red seaweeds possess good nutritional quality and could be used as an alternative source of dietary fiber, protein, and minerals [1]. Also seaweeds are considered as a source of bioactive compounds as they are able to produce a great variety of secondary metabolites, characterized by a wide range of biological activities such as antimicrobial [2-4], anti-inflammatory [5], anti-viral; as well as anti-tumoral activities [7,8]. Moreover, many studies show that some algal extracts display substantial antioxidant activities [9-12].

Antioxidant substances in seaweeds contribute to the endogenous defense mechanism against external stressful conditions [13]. Antioxidant properties of some red, brown and green algae extracts have shown that they vary proportion to the content of antioxidative compounds [14]. In fact, the antioxidant activity in algae acts via several processes and compounds such as lipophilic scavengers (carotenoids), enzymatic scavengers (catalase, superoxide dismutase and peroxidase), and polyphenols $[15,16]$.

Many studies indicated a close relationship between anticancer activity of algae and their contents of antioxidant compounds such as polyphenols and flavonoids. Seaweed extracts contain substantial amounts of polyphenols such as catechin, epicatechin, epigallocatechin gallate, and gallic acid, as reported in Halimeda sp. (Chlorophyceae) [17]. In addition, the extract of Ascophyllum spp. had a higher polyphenol content compared with other seaweeds, whereas Ulva spp. had the lowest content of these compounds $[18,19]$. Polyphenolic compounds inhibit cancer cells by xenobiotic metabolizing enzymes that alter metabolic activation of potential carcinogens, while some flavonoids can also alter hormone production and inhibit aromatase to prevent the development of cancer cells [20]. The mechanism of action of anticancer activity of phenolics may also occur by disturbing cellular division during mitosis at the telophase stage. Phenolics reduce the amount of cellular protein and mitotic index, as well as colony formation during cell proliferation of cancer cells [21]. Early studies proved a close relationship between antioxidant activities and total phenolic content $[22,23]$. Further, edible seaweed extracts like Palmaria palmate 
were shown to be effective antioxidants, capable of inhibiting cancer cell proliferation [16]. The alcoholic extract of the red alga Acanthophora spicifera exhibited tumoricidal activity on Ehrlich's ascites carcinoma cells developed in mice [24]. In addition, enzymatic and polysaccharides extracts from brown seaweeds strongly showed antioxidant potential with dose-dependent radical scavenging activities [25] and suppressed the in vitro proliferation of selected cancer cell lines [26]. Therefore, the aim of the present study was to determine the polyphenols content, antioxidant and anticancer activities of some marine algae from the Western coast of Tripoli (Libya).

\section{Materials and Methods}

\subsection{Experimental materials}

Seaweeds algal species including Chlorophyta (Ulva lactuca, and Codium tomentosum); Phaeophyta (Cystoseira crinita, Cystoseira stricta, and Sargassum vulgare), and Rhodophyta (Gelidium latifolium, Hypnea musciformis, and Jania rubens) were collected from the western coast of Libya in March, 2013. The algal samples were authenticated in the Botany Department, Faculty of Science, University of Tripoli. Human colorectal carcinoma (Caco2) and Human Corneal Epithelial Cells (HCEC) cell lines were obtained from the American Type Culture Collection (ATCC).

\subsection{Reagents}

Chemicals required for the assays including 1,1-diphenyl-2-picrylhydrazyl (DPPH) were purchased from Sigma-Aldrich (Saint-Louis, MO, USA). All other utilized reagents were of the highest available commercial grade.

\section{Methods}

\subsection{Algae extraction procedure}

Seaweed sampling and extraction: Samples were collected from the western part of the Libyan coast, in March 2013. Fresh seaweeds were rinsed with tap water and polished to remove any associated epiphytes, salt, sand, microorganisms and other suspended materials. Then, the clean material was air dried in a shady place at room temperature $\left(25-30^{\circ} \mathrm{C}\right)$ on absorbent paper, and then ground to a fine powder in an electrical coffee mill. The extraction was carried out according to Senevirathne et al. 
(2006) [27] with some modifications. Briefly, seaweeds (20g) were extracted with methanol $(100 \mathrm{~mL})$ in a shaking incubator at $25^{\circ} \mathrm{C}$ for $72 \mathrm{~h}$. The extracts were filtered with Whatman's No. 1 filter paper and re-extracted three times. The filtrate was concentrated under reduced pressure by using Rotary evaporator (Heidolph300 LabroRota, Germany). The oily residues were stored at $-20^{\circ} \mathrm{C}$ until analysis.

\subsection{Determination of Total Polyphenol and Flavonoid Content}

The total phenolic content was determined by the Folin -Ciocalteu method using gallic acids $(10-200 \mathrm{mg} / \mathrm{mL})$ as a standard and the absorbance measured at $720 \mathrm{~nm}$ [28]. Phenolic content of the extract was calculated as $\mathrm{mg}$ gallic acid equivalent (GAE) per gram of dried powder.

Total flavonoids content was assessed according to the method of Park et al. (2008) [29]. An aliquot of $0.3 \mathrm{~mL}$ of extracts was mixed with $3.4 \mathrm{~mL}$ of $30 \%$ methanol, 0.15 $\mathrm{mL}$ of $0.3 \mathrm{M} \mathrm{AlCl}_{3}-6 \mathrm{H}_{2} \mathrm{O}$ and $0.15 \mathrm{~mL}$ of $0.5 \mathrm{M} \mathrm{NaNO}_{2}$ in a test tube $(10 \mathrm{~mL})$, and then $1 \mathrm{~mL}$ of $1 \mathrm{M} \mathrm{NaOH}$ was added. Absorption was measured at $506 \mathrm{~nm}$. Flavonoids content was estimated from the standard calibration curve of 10-100 mgmL $L^{-1}$ rutin.

\subsection{Antioxidant activity Assays}

For antioxidant assays, all extracts $(1.0 \mathrm{mg} / \mathrm{mL}$ of extracts) were dissolved in $95 \%$ methanol and a series of concentration- dependent dilutions were made (40-300 $\mu \mathrm{g} / \mathrm{mL})$. Standard reagents were utilized for comparison for all antioxidant assays.

\subsubsection{DPPH Free radical scavenging activity}

Free radical-scavenging activities of extracts were measured using 2,2-diphenyl-1picrylhydrazyl (DPPH) as described by Dandlen et al., (2010) [30]. The percentage inhibition of the DPPH radical by the samples was calculated according to the following equation: \% Inhibition $=\left(\mathrm{A}_{0}-\mathrm{A}_{1}\right) / \mathrm{A}_{0} \times 100$, where $\mathrm{A}_{0}$ is the absorption of the blank sample ( $\mathrm{t}=0$ minutes) and $\mathrm{A}_{1}$ is the absorption of the tested extract solution ( $\mathrm{t}=60$ minutes). All determinations were performed in triplicate. The sample concentration providing 50\% inhibition ( $\mathrm{IC}_{50}$ ) was obtained by plotting the inhibition percentage against extracts concentrations. 


\subsubsection{Reducing power assay}

The reducing power of extracts was investigated following the method of Oyaizu (1986) [31]. Extract solution (2 mL), was mixed with potassium ferricyanide (2 mL, $10 \mathrm{mg} / \mathrm{mL})$ and phosphate buffer $(2 \mathrm{~mL}, 0.2 \mathrm{M}, \mathrm{pH} 6.6) \mathrm{kept}$ for $30 \mathrm{~min}$ at $45^{\circ} \mathrm{C}$. TCA $(2 \mathrm{~mL}, 100 \mathrm{mg} / \mathrm{l})$ was added to the reaction mixture. Two $\mathrm{mL}$ of distilled water and $0.4 \mathrm{~mL}$ of $0.1 \%(\mathrm{w} / \mathrm{v})$ ferric chloride were mixed with $2 \mathrm{~mL}$ of reaction mixtures in a test tube, after 10 minute reaction time the absorbance was measured at $700 \mathrm{~nm}$. Increase in absorption by the mixture indicated a higher reducing power.

\section{6. Determination of anticancer activity}

\subsubsection{Preparation of extracts for anticancer experiments}

The residues of algae extracts were individually dissolved in $1 \%$ dimethyl sulfoxide (DMSO, Sigma, St. Louis, USA) to a final concentration of $1 \mathrm{mg} / \mathrm{mL}$. For all experiments, the final concentrations of the tested compounds were prepared by diluting the stock with the culture medium.

\subsubsection{Cell lines and culture conditions}

Human colorectal carcinoma (Caco2) and Human Corneal Epithelial Cells (HCEC) cell lines were maintained in monolayer culture at $37^{\circ} \mathrm{C}$ and $5 \% \mathrm{CO}_{2}$ in Dulbecco's Modified Eagle's Medium (DMEM)supplemented with 10\% fetal bovine serum (FBS), $0.5 \%$ glutamine (20 mM, Gibco, Scotland, UK), $0.5 \%$ penicillin (100 IU/mL), Gibco, Scotland, UK), and non-essential amino acids (1\%). Stock cultures were sub-cultured every $7^{\text {th }}$ day after harvesting the cells with trypsin EDTA and then seeded in a tissue culture flask to maintain in exponential phase.

\subsubsection{Cytotoxicity assay}

Inhibition of cell proliferation by algal extracts was measured using the MTT assay. Cells $\left(2 \times 10^{4} /\right.$ well $)$ were plated in 96-well culture plates. After an additional $24 \mathrm{~h}$, various concentrations of crude algae extracts were added to the wells to obtain final concentrations of 50,100, 150 and $200 \mu \mathrm{g} / \mathrm{mL}$ and incubated for $72 \mathrm{~h}$ at $37^{\circ} \mathrm{C}$. After removal of the sample solution and washing with phosphate-buffered saline ( $\mathrm{pH} 7.4)$, 
$10 \mu \mathrm{l} /$ well $\quad(5 \mathrm{mg} / \mathrm{mL}) \quad$ of 3 -(4,5-dimethyl-2-thiazolyl)-2,5-diphenyl--tetrazolium bromide (MTT) in phosphate buffered saline (PBS) were added to each well, and incubated for $4 \mathrm{~h}$ at $37^{\circ} \mathrm{C}$. The medium was removed and formazan was dissolved in DMSO and the optical density was measured at $492 \mathrm{~nm}$ using a bioassay reader (Biorad, USA). The effect of the extracts on the proliferation of cells was expressed as the \% inhibition of growth. All experiments were performed at least twice in triplicate.

\subsubsection{Cell morphological analysis}

Caco 2 cells $\left(3 \times 10^{5}\right)$ were seeded in each well of $40 \mathrm{~mm}$ culture dishes and allowed to proliferate for 24 hours. After that, cells were treated with algae extracts at 50, 100,150 , and $200 \mu \mathrm{g} / \mathrm{mL}$. Control untreated cells were also included. Morphological changes of cells untreated and treated with algae were performed by inverted light microscope (Olympus, Tokyo, Japan) after 72 hours.

\subsubsection{Cell cycle analysis by flow cytometry}

To determine cell cycle distribution analysis, $1 \times 10^{6}$ cells were plated in $25 \mathrm{~cm}^{2}$ tissue culture flasks, treated with extracts of all tested algae $(200 \mu \mathrm{g} / \mathrm{mL})$ for $72 \mathrm{~h}$. After treatment, the cells were collected by trypsinization, fixed in $70 \%$ cold ethanol, washed in PBS, resuspended in $1 \mathrm{~mL}$ of PBS containing $1 \mathrm{mg} / \mathrm{mL}$ RNAse. The cells were then incubated for $30 \mathrm{~min}$ at $37^{\circ} \mathrm{C}$, after which, $5 \mu \mathrm{L}$ of propidium iodide (1 $\mathrm{mg} / \mathrm{mL}$ ) was added to the cells and vortexed. Measurements were carried out on flow cytometer, (BD Facs Canto) and the data were analysed with BD FacsDiva software; the results are expressed as a percentage of the cells in each phase [32].

\subsection{Statistical analysis}

The experiments were performed in triplicate and all data are expressed as mean \pm standard deviation. The values were analyzed by one-way ANOVA using SPSS version 16.0 software and individual comparisons were obtained by Tukey's method. $P$ value $\leq 0.05$ was considered statistically significant.

\section{Results and discussion}

\subsection{Polyphenolics and flavonoids content}


Phenolic compounds are commonly found in plants, encompassing seaweeds, and have been reported to have a wide range of biological activities including antioxidant and anticancer activities [29,33]. Nevertheless, in Libya, little information about the polyphenols and flavonoids concentrations in Libyan coast seaweeds is available. The current study showed for the time the amounts of polyphenols and flavonoids in tested algae as well as their anticancer activity.

Results (Table 1) revealed that the amount of total phenolic and total flavonoid contents in the alcoholic extracts of $C$. crinita and $J$. rubens were $800.28 \pm 36.23$ $\mathrm{mg} / \mathrm{g}$ and $600.33 \pm 31.53 \mathrm{mg} / \mathrm{g}$ dry weight expressed as gallic acid equivalents, and $474.72 \pm 26.51 \mathrm{mg} / \mathrm{g} 435.79 \pm 25.61$, expressed as rutin equivalents, respectively (Table 1); these levels were significantly higher than those reported for other seaweeds $(P<0.05)$ [17]. In addition, the total phenolic content and flavonoids contents in extracts of $U$. lactuca were markedly higher than in $C$. tomentosum $(P<$ 0.05) (Table 1).

\subsection{Antioxidant activity}

Screening of potential antioxidant activities of methanolic crude extracts from eight species of seaweeds was performed using two antioxidant assays; reducing power and DPPH.

As a result of the presence of a high level of polyphenols including phenolic acids, flavonoids, isoflavones, cinnamic acid, benzoic acid, quercetin in algae, these algal extracts are reliable sources antioxidants [12].

Table 1. Total polyphenol and flavonoid contents of methanolic extracts of the tested algae.

\begin{tabular}{lcc}
\hline & $\begin{array}{c}\text { Polyphenols content } \\
*(\mathrm{mg} \text { GAE/g DW })\end{array}$ & $\begin{array}{c}\text { Flavonoids content } \\
(\mathrm{mg} \text { Rutin/g DW })\end{array}$ \\
\hline Chlorophyta & $440.50 \pm 39.13^{\mathbf{a}}$ & $368.07 \pm 25.72^{\mathbf{a}}$ \\
U. lactuca & $300.17 \pm 35.38^{\mathbf{b}}$ & $268.07 \pm 25.72^{\mathbf{c}}$ \\
$\begin{array}{l}\text { C. tomentosum } \\
\text { Phaeophyta }\end{array}$ & & \\
C. crinita & $800.28 \pm 36.23^{\mathbf{c}}$ & $474.72 \pm 26.51^{\mathbf{a}}$ \\
C. stricta & $430.6 \pm 30.13^{\mathbf{a}}$ & $356.59 \pm 29.31^{\mathbf{b}}$ \\
S. vulgare & $350 \pm 26.28^{\mathbf{b}}$ & $251.67 \pm 25.5^{\mathbf{d}}$ \\
Rhodophyta & & \\
H. musciformis & $256.44 \pm 24.18^{\mathbf{d}}$ & $203.02 \pm 24.07^{\mathbf{d}}$
\end{tabular}




$\begin{array}{lll}\text { J. rubens } & 600.33 \pm 31.53^{\mathrm{e}} & 435.79 \pm 25.61^{\mathbf{a}} \\ \text { G. latifolium } & 368.63 \pm 21.53^{\mathbf{b}} & 298.65 \pm 18.01^{\mathbf{c}}\end{array}$

DW: dry weight; Results were recorded as (mean \pm SD); *mg GAE/g DW: milligram gallic acid equivalent per gram dry weight; mg Rutin /g DW: milligram Rutin equivalent per gram dry weight. Each value is presented as mean $\pm \operatorname{SD}(n=3)$. Means within each column with different letters $(a-f)$ differ significantly $(P<0.05)$.

\subsubsection{Antioxidant scavenging activity}

Much experimental data emphasizes that plants including seaweeds are rich sources of antioxidant compounds. The reactive oxygen species (ROS) attack biomolecules, producing unfavorable changes in DNA, lipids, and proteins and are implicated in the pathogonsis of many diseases. Any natural or synthetic compound with antioxidant properties might contribute towards the partial or total alleviation of this damage [34]. All algal extracts possessed radical scavenging activity, although C. crinita was more effective in scavenging DPPH with lowest IC50 (Table 2).

The antioxidant activity is proportional to the concentration of polyphenols and flavonoids. The maximum scavenging effect was shown by the extract of C. crinita, C. stricta and S. vulgare with the $\mathrm{IC}_{50}$ values of $50.5,75.11$ and $150 \mu \mathrm{g} / \mathrm{mL}$ respectively (Table 2), this is in a good agreement with previous findings that brown algae have higher than antioxidant activity red or green algae [10]. The lowest scavenging ability was shown by $C$. tomentosum and G. latifolium with higher $\mathrm{IC}_{50}$ $(300 \mu \mathrm{g} / \mathrm{mL})$. The present study showed that the green algae collected from Libyan coast have very low antioxidant power which is in line with the other reports on the other green algae reports $[14,35]$.

Table 2. Antioxidant activity of selected algae

\begin{tabular}{lc}
\hline & $\begin{array}{c}\text { DPPH* } \\
\text { IC }_{\mathbf{5 0}} \boldsymbol{\mu} \mathbf{g} / \mathbf{m L}\end{array}$ \\
\hline Chlorophyta & \\
U. lactuca & $230.50 \pm 9.03^{\mathrm{a}}$ \\
C. tomentosum & $300.17 \pm 35.38^{\mathrm{b}}$ \\
Phaeophyta & \\
C. crinita & $50.5 \pm 3.20^{\mathrm{c}}$ \\
C. stricta & $75.11 \pm 30.13^{\mathrm{d}}$ \\
S. vulgare & $150 \pm 26.28^{\mathrm{e}}$
\end{tabular}




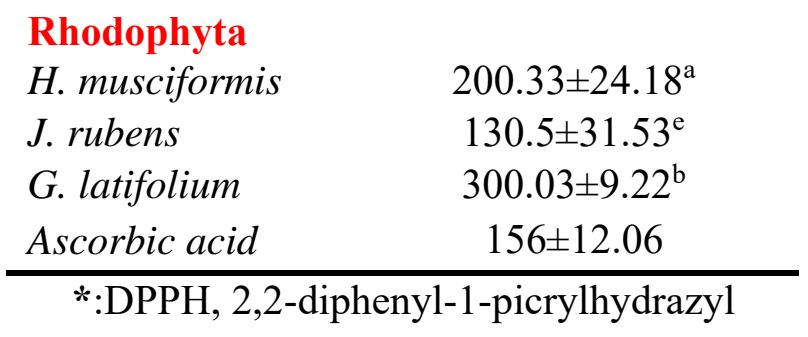

\subsubsection{Reducing power}

Reducing capacity is considered as a significant additional indicator of potential antioxidant activity of a compound or sample [36].

Figure 1 shows the concentration-response curves for the reducing power of the algal extracts under investigation. In general, the reducing power of the extract also increased with an increase in concentration applied. There were significant differences between the reducing power of extracts (A, B and C) and that of ascorbic acid that was used as positive control $(P<0.01)$ (Figure 1D).

The present study indicate that the alcoholic extracts of the brown algae C. crinite, $C$. stricta and S. vulgare possessed good reducing power, followed by red algae $H$. musciformis and G. latifolium (Figure $1 \mathrm{~B} \& \mathrm{C}$ ) showing a steady increase in reductive potential of the brown seaweed with an increase in the absorbance in a concentrationdependent manner. On the other hand, green algae (C. tomentosum and U. lactuca) extracts showed low reducing power (Figure 1A). The results obtained correlate with the total phenolic and flavonoids contents (Table 1), indicating that these algae could potentially be a good source of natural and easy extractable antioxidants for pharmaceutical, dietary and cosmetic purposes. 

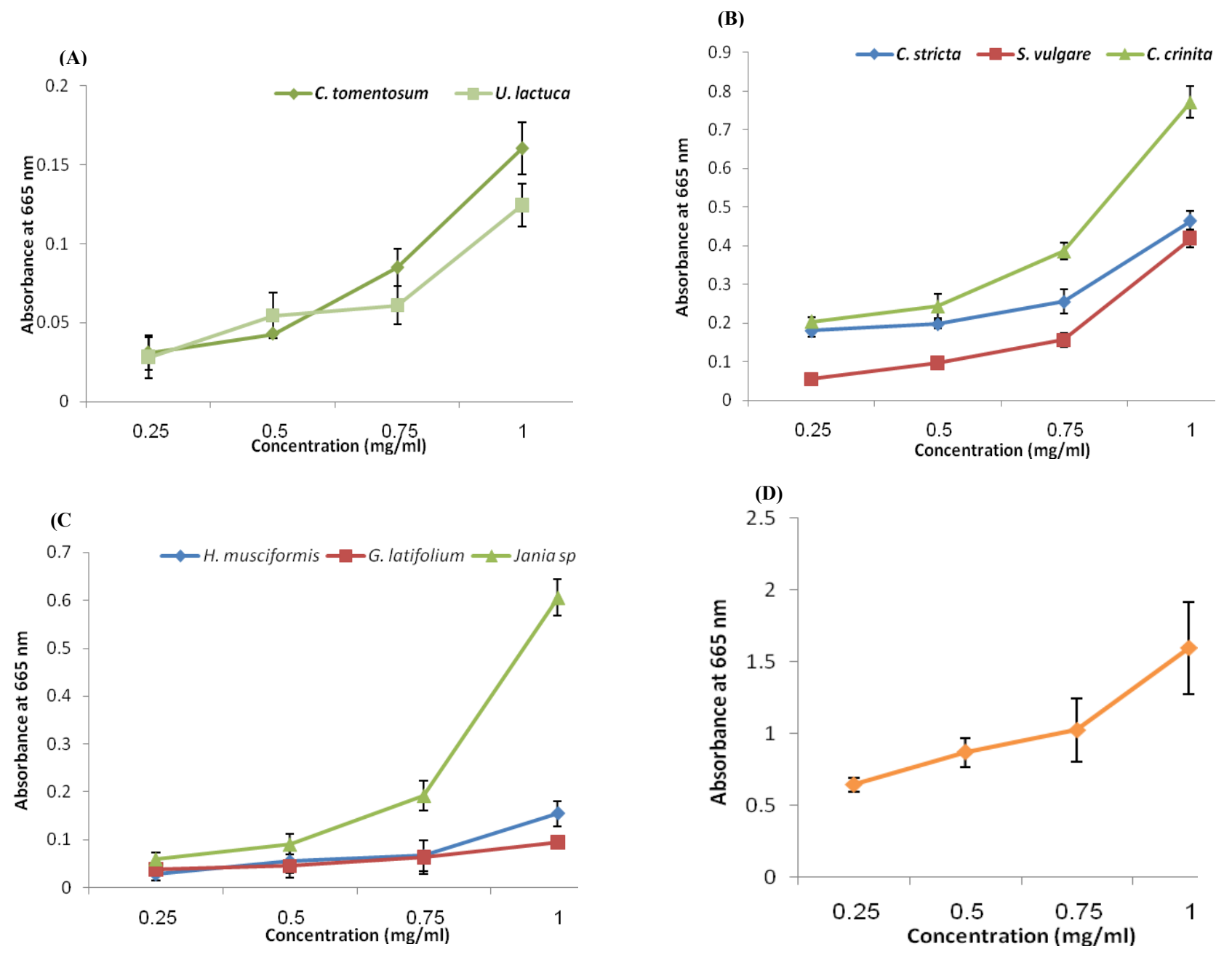

Figure 1. Reducing potential of crude algae extracts determined by reducing power assay. Data are mean $\pm \mathrm{SD}$. (A) green algae; (B) brown algae, (C) red algae extracts and (D) ascorbic acid (positive control).

\subsection{Anticancer activity}

\subsubsection{Cytotoxic activity of crude algae extracts}

Cytotoxicity is an activity that is consistent with anticancer activity, the major advantage of cytotoxicity assays is that all potential mechanisms of cellular proliferation can be monitored simultaneously. In the present study, colon cancer cell line (Caco2) was used to determine the cytotoxic activity of crude algae extracts at various concentrations (50, 100,150 and $200 \mu \mathrm{g} / \mathrm{mL}$ ) (Figure 2). Under the same experimental conditions, the extracts were additionally tested using Human Corneal Epithelial Cells (HCEC) cell lines in order to examine their cytotoxic effect on normal cells (Figure 3). 
Figure 2, shows the percentage changes in the growth inhibition of cancer cells treated with algae extracts. The tested algae extracts especially $C$. crinite extract, showed a strong selective cell proliferation inhibition of the cancer cell line. This might be due to high polyphenols and flavanoids contents of the $200 \mu \mathrm{g} / \mathrm{mL}$ extract, which showed had maximum growth inhibition (87.05\%). At the same concentration, cells treated with $C$. tomentosum extract containing a low content of flavonoids and polyphenols, exhibited the lowest growth inhibition (46.2\%). The experimental observation indicted that cell death was a concentration-dependent process, hence the number of non-viable cells increased with increasing concentration of algal extracts.

Among brown algae, the $C$. crinita extract induced highly significant cytotoxic effect on the Caco2 cells after $72 \mathrm{~h}$ exposure; the percentage of inhibition was $87 \%$ at $200 \mu \mathrm{g}$ $\mathrm{mL}^{-1}$ compared to lower inhibition (\%) of extracts of C. stricta and S. vulgare $(P<0.01)$ (Figure 2B); this was in agreement with observations of previous study [9]. The extensive research on the crude extracts of various brown algae against different cancer cell lines shows promising anticancer potential [37].

In red algae extracts, G. latifolium extract displayed a substantial inhibition effect $(85 \%)$ at $200 \mu \mathrm{g} / \mathrm{mL}$, in comparison with cells treated with $H$. musciformis extract ( 48\%) (Figure 2C). In comparison with tested green algae extracts, U. lactuca caused significant cytotoxicity at the very low concentration $(50 \mu \mathrm{g} / \mathrm{mL} ; 55 \%)(P<0.01)$ and higher cytotoxic effect, in a dose-dependent manner in the range 50-200 $\mu \mathrm{g} \mathrm{mL}^{-1}$ $(55,60,70$ and $77 \%)$ (Figure $2 \mathrm{~B})$. In contrast, all tested algae displayed a nonsignificant cytotoxic effect on human normal HCEC cell line where the percent of inhibition did not exceed $24 \%$ at $200 \mu \mathrm{g} / \mathrm{mL}$ (Figure 3).

$\mathrm{IC}_{50}$ obtained against $\mathrm{Caco} 2$ cell line in the presence of the crude extract of C. crinita, C. stricta, S. vulgare were; $>50 \mu \mathrm{g} / \mathrm{mL}, 120 \mu \mathrm{g} / \mathrm{mL}$ and $150 \mu \mathrm{g} / \mathrm{mL}$ respectively. In contrast, the $\mathrm{IC}_{50 \mathrm{~S}}$ obtained against $\mathrm{Caco} 2$ cell line in the presence of the crude extracts of H. musciformis, J. rubens, G. latifolium were; $>200 \mu \mathrm{g} / \mathrm{mL}, 50 \mu \mathrm{g} / \mathrm{mL}$ and $120 \mu \mathrm{g} / \mathrm{mL}$ respectively. Moreover $\mathrm{IC}_{50}$ obtained against $\mathrm{Caco}_{2}$ cell line in the presence of the crude extract of U. lactuca, C. tomentosum were; $50 \mu \mathrm{g} / \mathrm{mL}$, and $>200$ $\mu \mathrm{g} / \mathrm{mL}$ respectively. The low $\mathrm{IC}_{50}$ values of C. crinite, J. rubens and U. lactuca indicate promising anti-proliferation activity of their extracts. 
Recent phytochemical studies, confirm the presence of bioactive compounds such as saponins, flavanoids, tannins and polyphenolic components in most tested algae [4, 38]. Therefore, the cytotoxic effect of algae, via the inhibition of the proliferation of Caco2 cells is likely to be related to their content of these compounds especially polyphenolics and flavonoids [39]. For example, quercetin shows antioxidant activity that is believed to have a cytoprotective role against oxidative stress [40]. In addition, the presence of 2,3-double bond in flavonoid molecules correlates with mitochondrial damage and cancer cell death [41].

A good correlation was observed between the total polyphenol contents and proliferation activity in seaweed extracts $\left(\mathrm{R}^{2}=0.686\right)$ (Figure 4$)$. The anticancer activity of polyphenols could be induced via multiple anticancer pathways such as interaction with key enzymes in cellular signaling pathways, cell cycle, apoptosis and metastasis $[42,43]$.

\subsubsection{Cell morphology study by inverted light microscope}

The ability of algal extracts to induce cell death was estimated by analyzing its effect on cell morphology (Figure 5). The observation of Caco2 cells under a phase contrast microscope showed that after $48 \mathrm{~h}$ of treatment with $200 \mu \mathrm{g} / \mathrm{mL}$ extracts, detectable changes were found, including altered cell morphology, cell shrinkage and membrane blebbing, the characteristic features of apoptotic cell death (Figure 5).

It is vital to maintain the homeostasis between cell proliferation and cell death in normal mammalian tissues; therefore, the process in which the rate of cell proliferation exceeds that of cell loss in tumor cells might be suppressed or perturbed [44]. In the present study, the cell cycle phase distribution of Caco2 cells treated with $200 \mu \mathrm{g} / \mathrm{mL}$ algal extracts for 72 hours is represented in Figure 6. Crude extracts blocked proliferation of Caco 2 cells by arresting the cell cycle. Flow cytometric analysis indicated G2-M block in algae-treated cells along with significant increase in the sub-diploid cell population (sub-G1). Onset of G2-M cell cycle arrest along with increase in the sub-diploid cell population (sub G1) suggests that the extracts were potent enough to induce both G2-M phase cell cycle arrest and apoptosis (Figure 6). 
Previous studies reported that some algae extracts inhibited cell growth in a dose- and time-dependent manner, by arresting cell-cycle progression and by promoting apoptosis in the HCT-116 colon cancer cell line [45]. Figure 7 shows cell cycle phase distribution of control and treated cells with green, brown and red algae extracts (200 $\mu \mathrm{g} / \mathrm{mL}$ ) for 72 hours. The data indicated that the treated Caco 2 cells in the G1 phase decreased with a concomitant increase in the sub-G peak

The brown algae mainly C. crinita extracts arrested the cells in a post G1 and G phases, and the numbers of sub $\mathrm{G}$ and $\mathrm{G}$ cells gradually increased significantly from $3.9 \%, 37.2 \%$ to $37.2 \%$ to $51.6 \%$ respectively after treatment $(P<0.05)$ (Figure $7 \mathrm{~b})$, in accord with previous findings [37]. Among tested red algae, most cells treated with H. musciformis extract, arrested in $\mathrm{G}$ phase (57.6\%) (Figure 7c), whereas cells treated with $U$. lactuca extract showed a decrease to $53.4 \%$ (Figure 7a). These results suggest that algae extracts especially brown algae are promising candidates for further investigation .

Many chemotherapeutic agents are found to be selectively toxic to tumor cells because they increase oxidant stress and enhance these already stressed cells beyond their limit [46]; in contrast, the anticancer activity of plant compounds may be attributed to their high affinity to the target, little loss of entropy when they bind to a protein and their bioavailability. Moreover, plant compounds are considered to have conformational flexibility in aqueous and lipophilic environments [47] and may act as good alternative anti-cancer agents.

There is growing need for the development and or discovery of highly potential bioactive compounds from natural sources due to the resistance to chemical drugs.

\section{Conclusion}

The present study elucidated for the first time the antioxidant and anticancer properties of eight Libyan seaweeds. The results reveal that among tested algae, $C$. crinita, C. stricta, J. rubens and U. lactuca extracts possess high antioxidant and antiproliferative activities which might be helpful in preventing or slowing the progress of various oxidative stress related disorders. However, further investigation is needed to assess the molecular mechanisms of the potential anticancer activities of 
these algae extracts as well as to identify of the bioactive compounds in the algae extracts and their commercial potential and applications in medicine, food production and in the cosmetic industry.
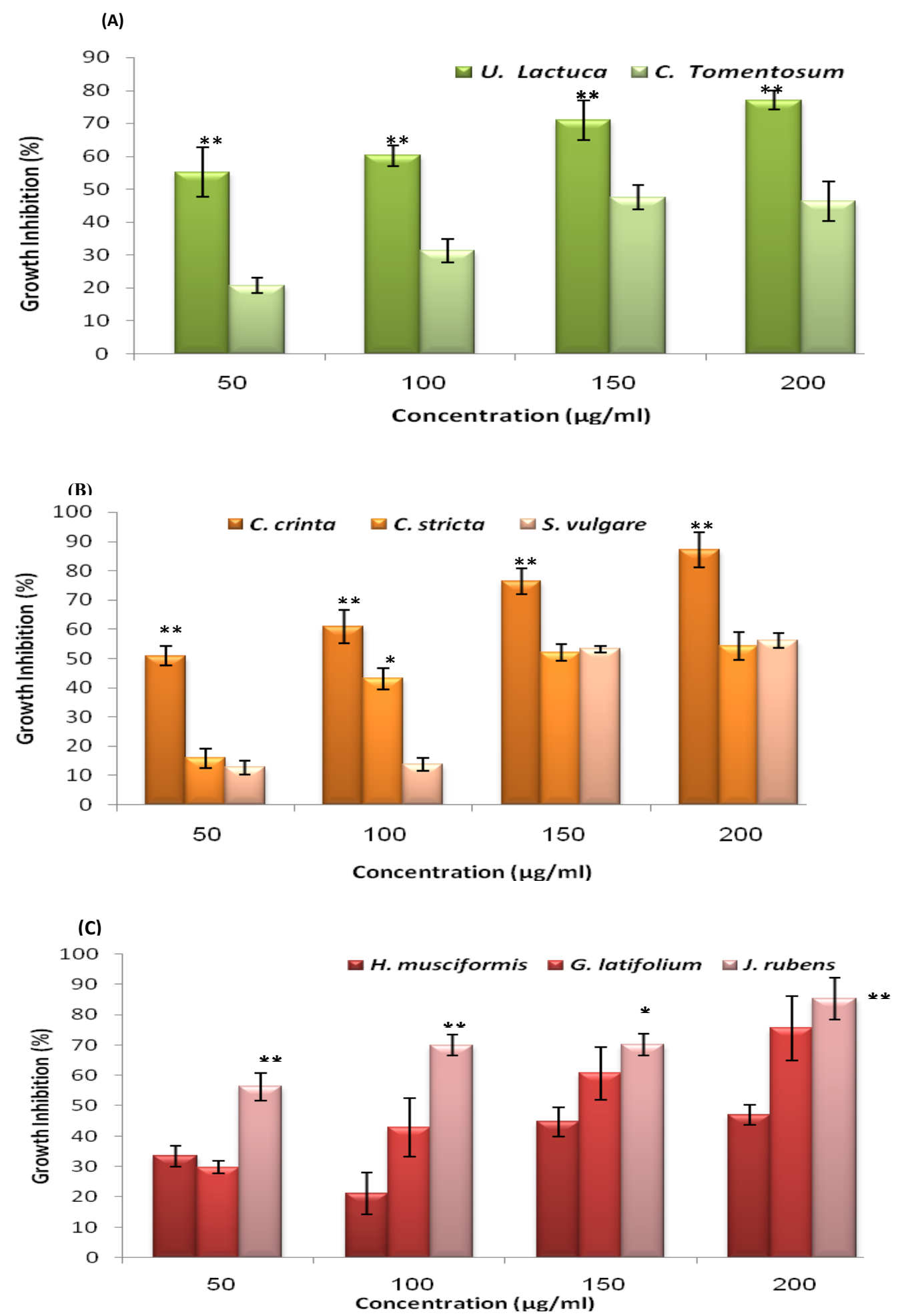
Figure. 2. antiproliferative effects of selected Libyan seaweeds: (A) Chlorophyta algae (U. lactuca, C. tomentosum), (B) Phaeophyta algae (C. crinite, C. stricta, S. vulgare) and (C) Rhodophyta algae (H. musciformis, J. rubens, G. latifolium) extracts on Caco2 cells. The cells were treated with increasing concentration of algae extracts for 72 hours. Cytotoxicity activity of the extracts was evaluated by MTT assay. Results were reported as mean $(n=6)$ percent of inhibition of cell growth with error bars showing the standard deviation. Asterisks indicate significant cytotoxicity relative to the control $\left({ }^{*} P<.05\right.$, **P $P 0.01)$.

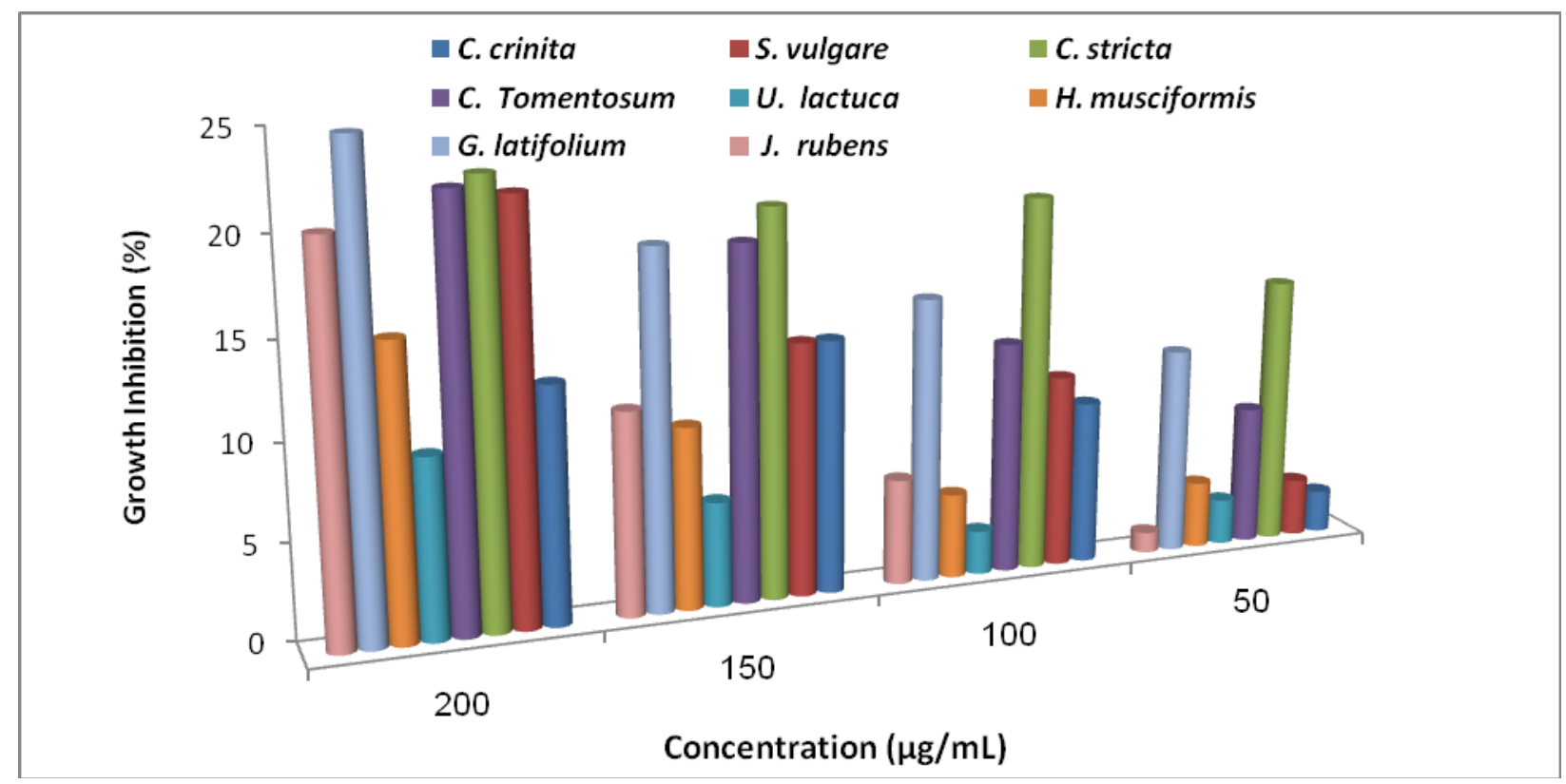

Figure 3: Antiproliferative effects of selected Libyan seaweeds ( $U$. lactuca, C. tomentosum, C. crinite, C. stricta, S. vulgare and $H$. musciformis, J. rubens, G. latifolium) extracts on HCEC cells line. The cells were treated with increasing concentration of algae extracts for 72 hours. 


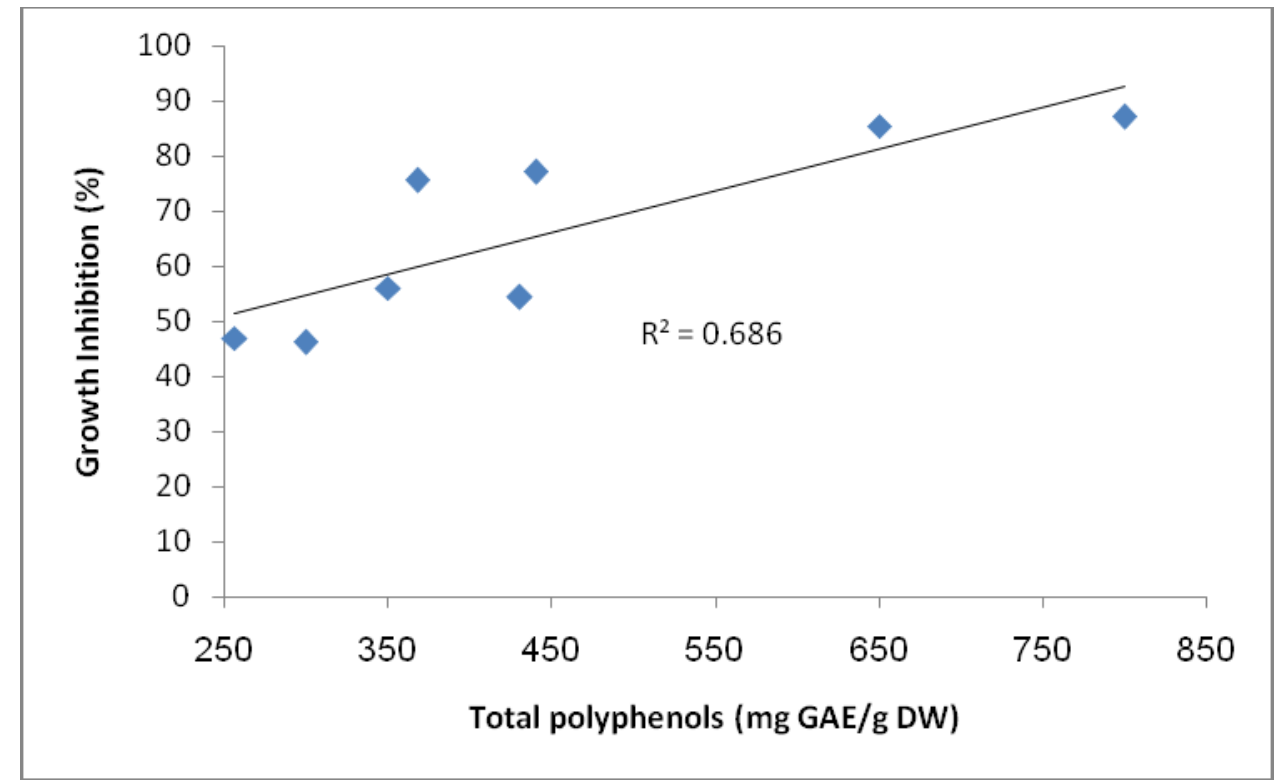

Figure 4: Correlation between the contents of total phenols in seaweeds and anticancer activity of extracts. 
(a)

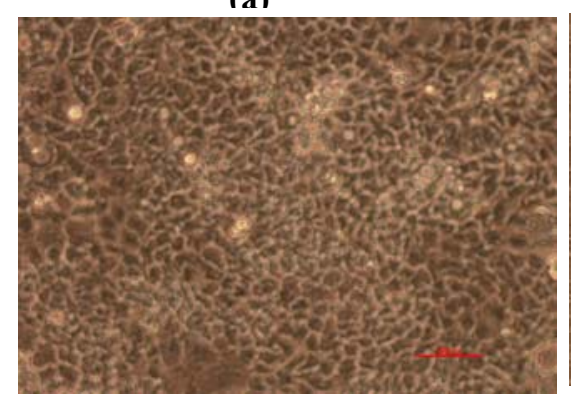

(d)

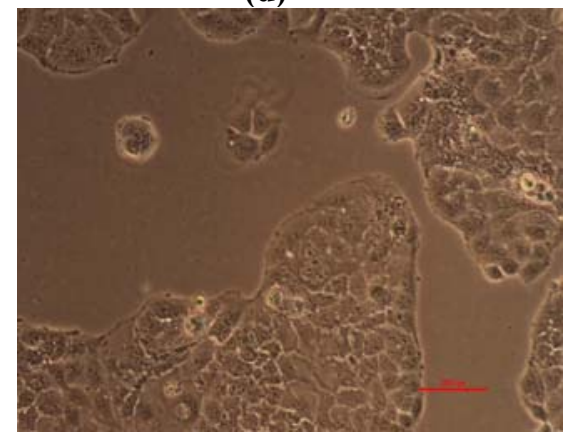

(g)

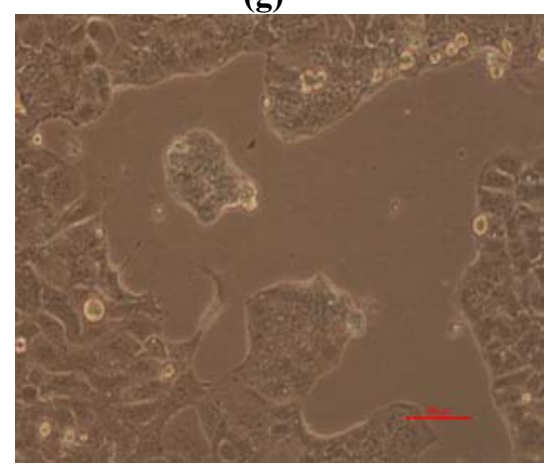

(b)

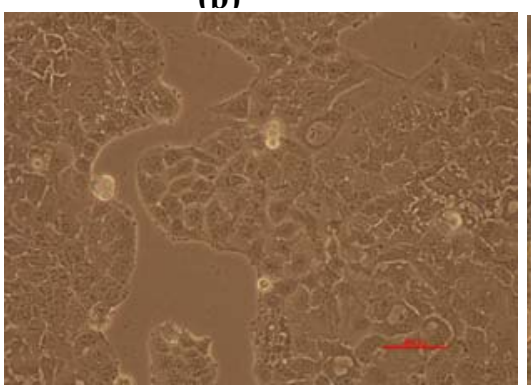

(e)

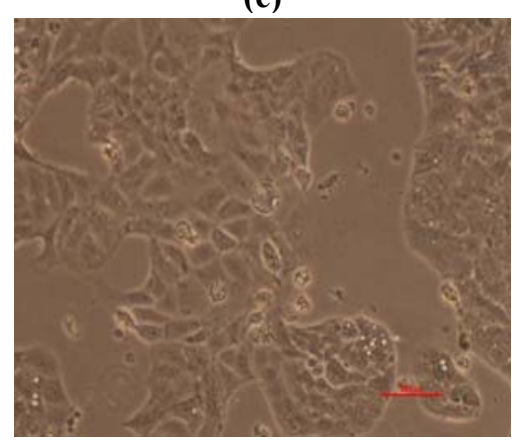

(h)

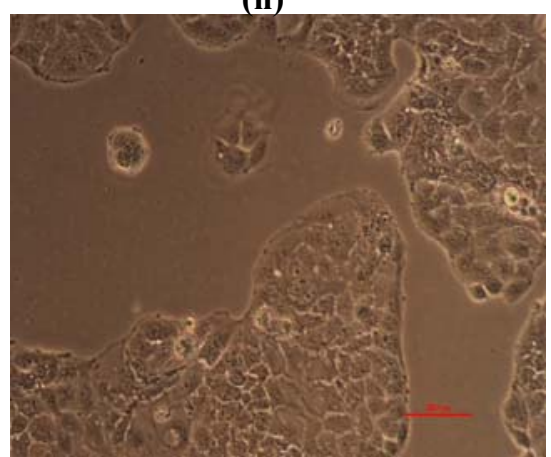

(c)

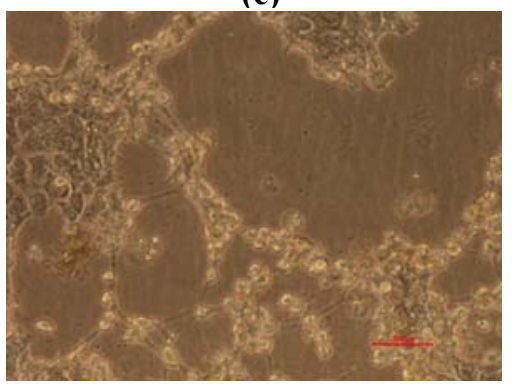

(f)

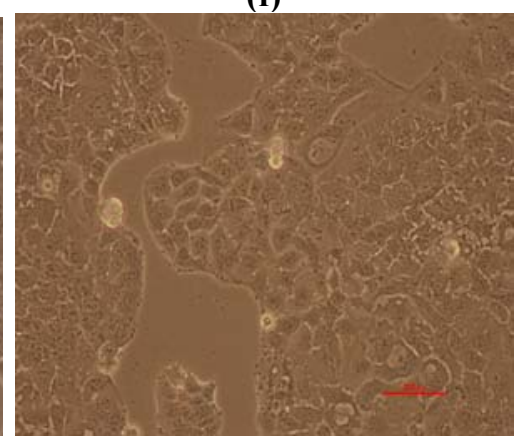

(i)

Figure 5. Morphological changes of cells untreated and treated with seaweeds extracts observed under an inverted light microscope (Olympus, Tokyo, Japan). Caco-2 cells were incubated for $48 \mathrm{~h}$ in the absence (a) and presence of $(200 \mu \mathrm{g} / \mathrm{mL})$ of $S$. vulgare (b), C. crinita (c) C. stricta (d), H. musciformis (e), J. rubens (f), G. latifolium (g), C. tomentosum (h), U. lactuca (i) extracts. Control cells appeared healthy and confluent while (b, c and d) treated cells was unwell and most cells were detached. Mag. X100. 


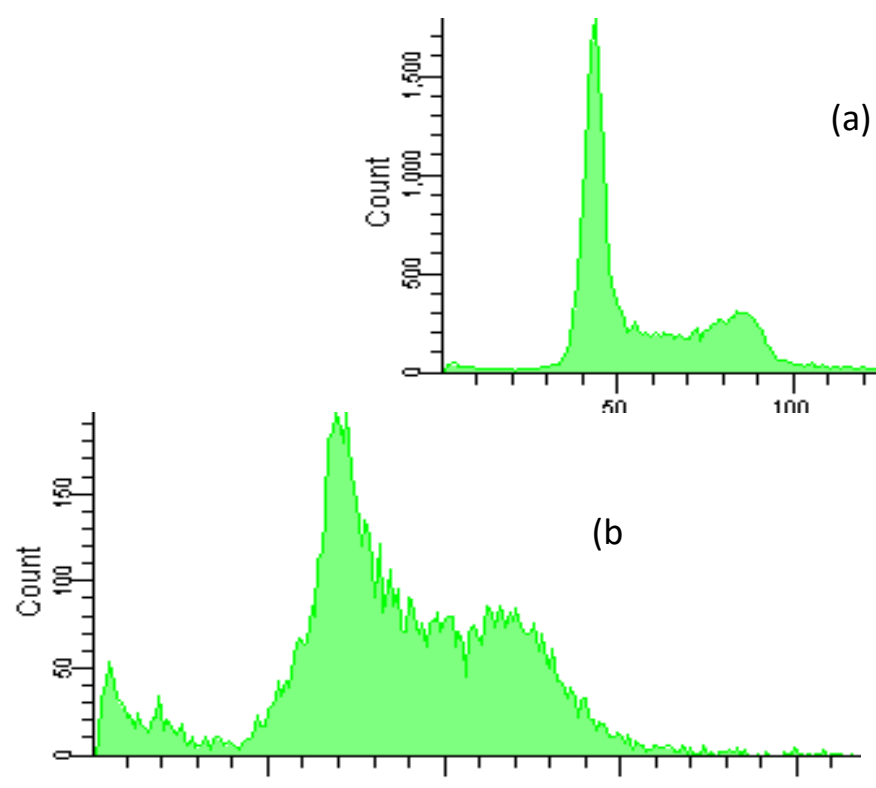

(a)
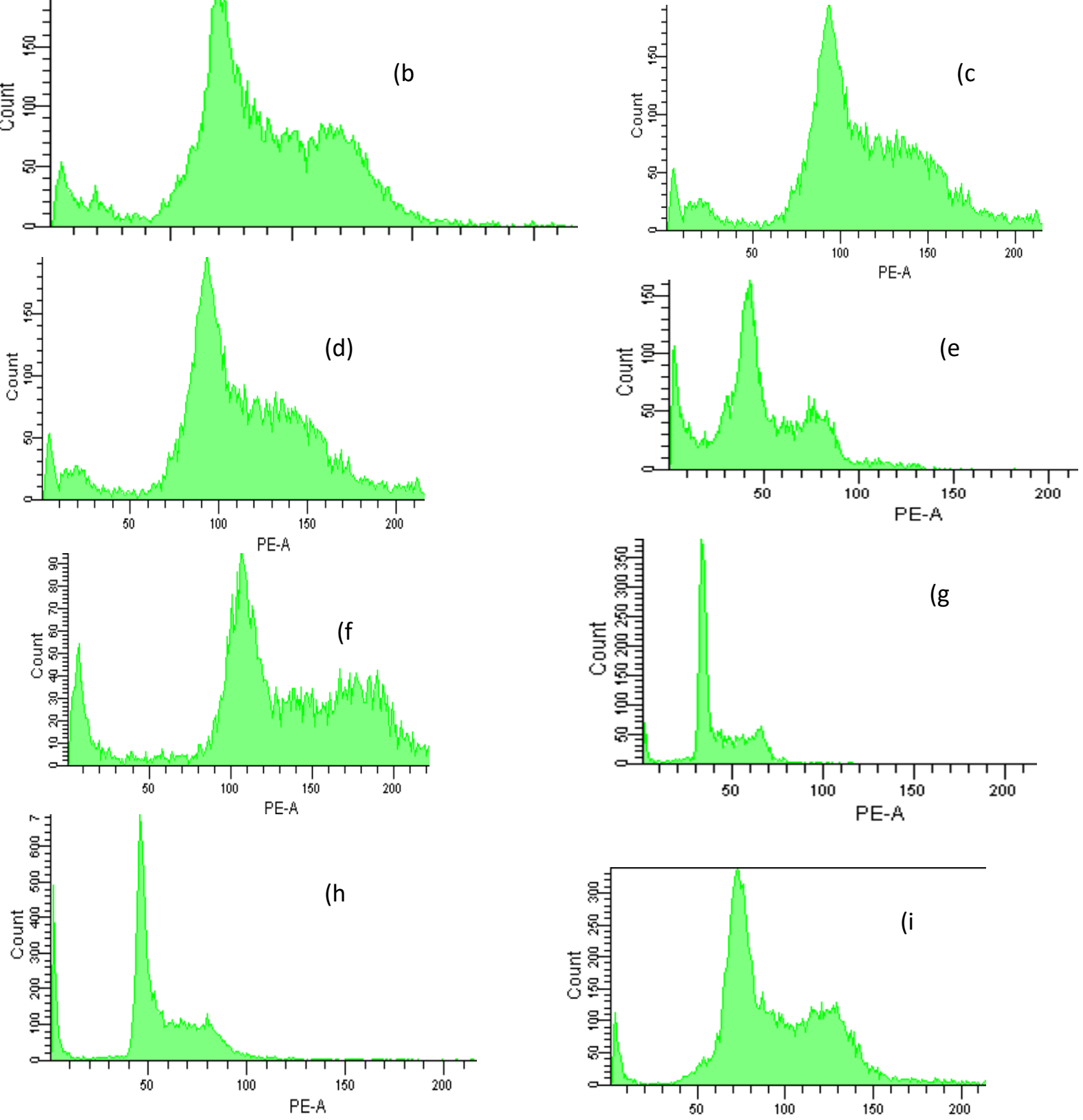

Figure 6. Cell cycle analysis of $\mathrm{CaCo} 2$ cancer cells treated with

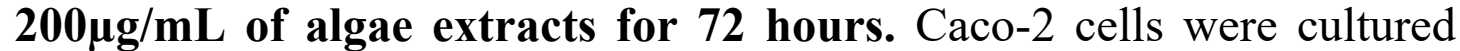
with control (a) and presence of C. crinita (b), C. stricta (c), S. vulgare (d), J. rubens (e), H. musciformis (f), G. latifolium (g), U. lactuca (h), C. tomentosum (i). 


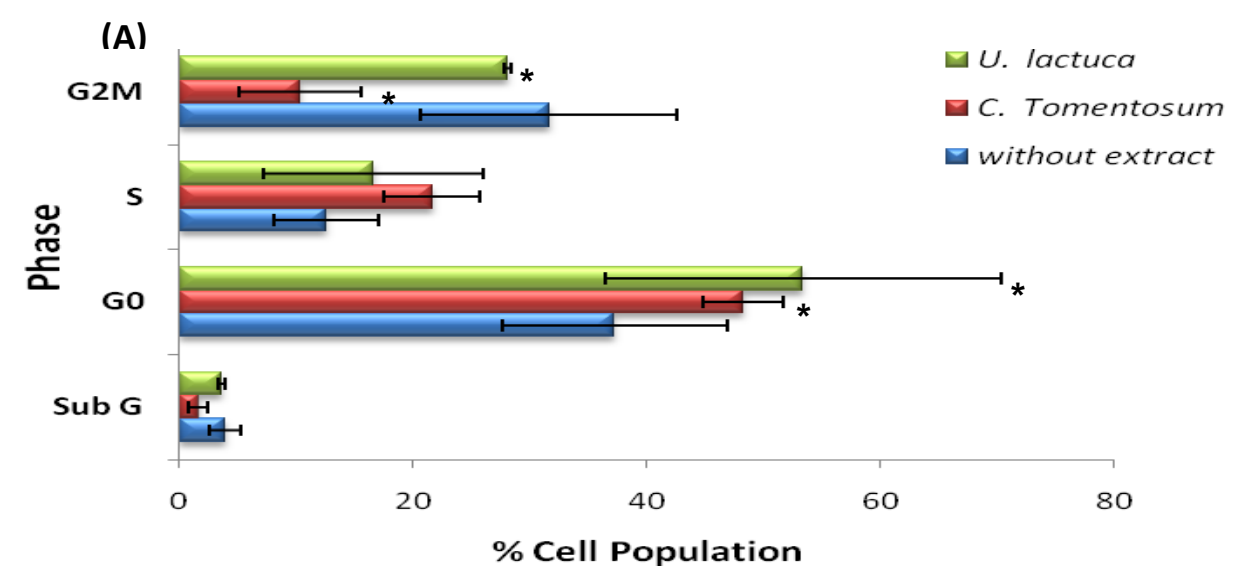

(B)
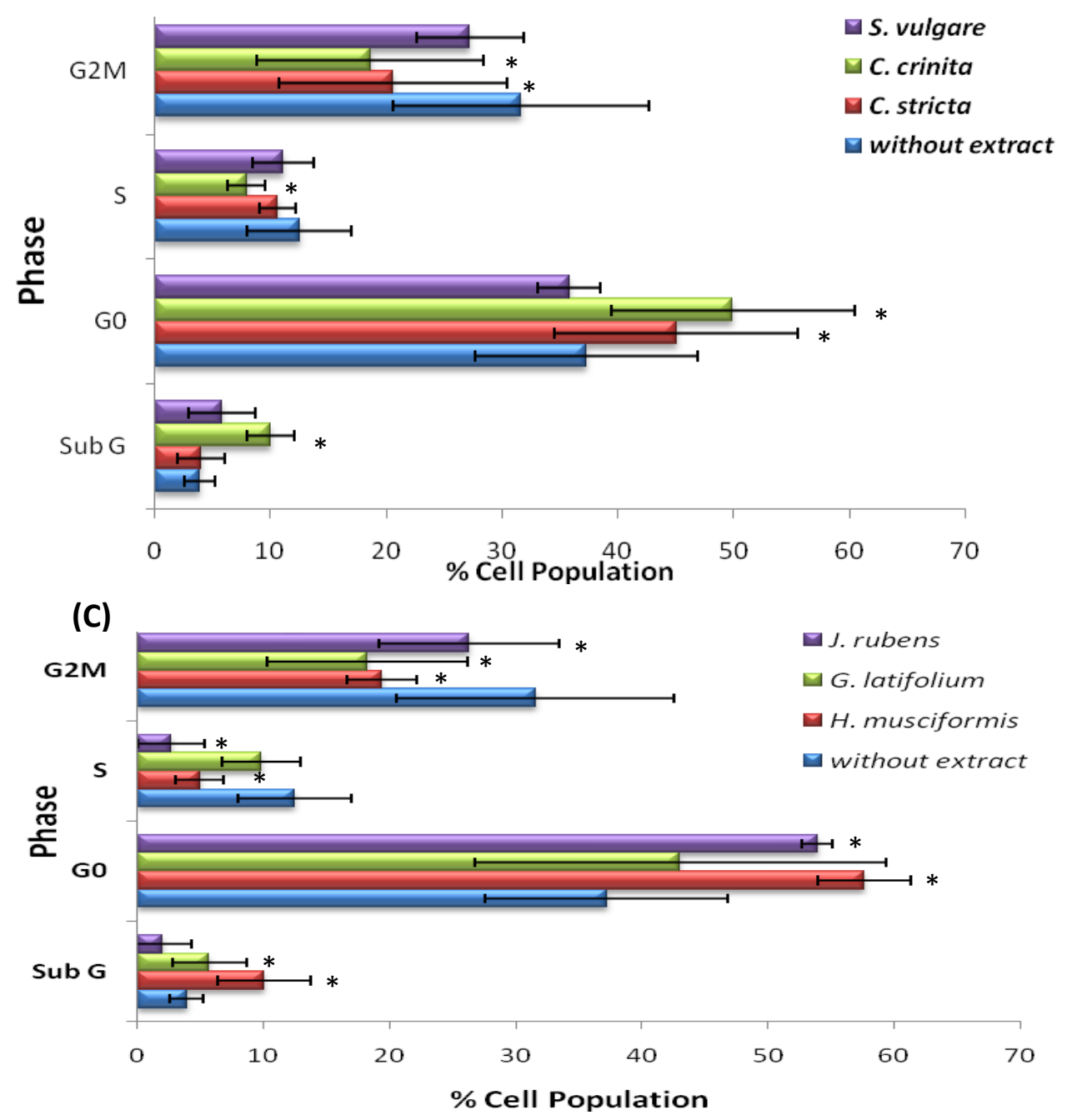

Figure 7. Effect of algal extracts on Caco2 Cell Cycle after 72 hours incubation. Cells were fixed with ethanol and stained with propidium iodide, and then cell cycle distribution was analyzed by flow cytometry. Bar charts representing the percentage of cell populations in Caco2 cells treated with $200 \mu \mathrm{g} / \mathrm{mL}$ extracts of (A) green algae; and (B) brown algae; (C) red algae. The asterisk indicates a significant difference between control and algal-treated cells, $(* P<0.05)$. 


\section{Acknowledgements}

This work was financially supported by university of Tripoli, Tripoli, Libya

\section{Conflict of interest}

None declared.

\section{References}

1. Fitton JH. Antiviral properties of marine algae. In: Critchley AT, Ohno M, Largo DB (org.). World seaweed resources-An authoritative reference system. ISBN 90 7500080 4, UK, ETI Information Services. DVD-Rom. 2006

2. Newman, D.J.; Cragg, G.M.; Snader, K.M. Natural products as source of new drugs over the period 2002-1981 J. Nat. Prod. 2003,66, 1022-1037.

3. Stirk WA.; Reinecke DL.; Staden J. Seasonal variation in antifungal, antibacterial and acetylcholinesterase activity in seven South African seaweeds. J. Appl. Phycol. 2007,19, 271-276

4. Alghazeer, R.; Whida, F.; Gammoudi,; F. Nailia.; M. Abduelrhman, E. In vitro antibacterial activity of alkaloid extracts from green, red and brown macroalgae from western coast of Libya. Afr J Biotechnol. 2013,12;51, 7086-7091

5. Lindequist, U., Schweder, T. Marine biotechnology. In: Rehm, H.J., Reed, G. (E ds. ), Biotechnology. Wiley- VCH, Weinheim. 2001, 10, $441-484$.

6. Rabanal M.; Ponce N.; Navarro D.A.; Gómez R.M.; Stortz C. A. The system of fucoidans from the brown seaweed Dictyota dichotoma: Chemical analysis and antiviral activity. Carbohyd Polym. 2014, 101, 804-811

7. Zandi, K.; Ahmadzadeh, S.; Tajbakhsh.S.; Rastian, Z.; Yousefi, F.; Farshadpour, F.; Sartavi, K. Anticancer activity of Sargassum oligocystum water extract against human cancer cell lines. Eur Rev Med Pharmacol Sci. 2010,14, 669-673.

8. Ale, M.T.; Maruyama, H.; Tamauchi, H.; Mikkelsen, J.D.; Meyer, A.S. Fucoidan from Sargassum sp. and Fucus vesiculosus reduces cell viability of lung carcinoma and melanoma cells in vitro and activates natural killer cells in mice in vivo. Int. J. Biol. Macromol. 2011, 49, 331-336.

9. Zubia, M.; Fabre, M. S.; Kerjean, V. et al. Antioxidant and antitumoural activities of some Phaeophyta from Brittany coasts, Food Chem, 2009, 116, 693-701. 10. Lekameera R.; Vijayabaskar P.; Somasundaram ST. Evaluating antioxidant property of brown alga Colpomenia sinuosa (DERB. ET SOL). African J Food Sci. 2008, 2, 126-130. 
11. Cox, S.; Abu-Ghannam, N.; Gupta, S. An assessment of the antioxidant and antimicrobial activity of six species of edible Irish seaweeds. International Food Research Journal 2010,17, 205-220.

12. Keyrouz, R.; Abasq, M.L.; Le Bourvellec, C. Total phenolic con-tents, radical scavenging and cyclic voltammetry of seaweeds from Brittany. Food Chem. 2011, $126,831-836$.

13. Ranjala, R.; Yanxia, L.; Valerie J.; Paul, Hendrik, L. Cultivated Sea Lettuce is a Multiorgan Protector from Oxidative and Inflammatory Stress by Enhancing the Endogenous Antioxidant Defense System. Cancer Prev Res (Phila). 2013, 6,989

14. Zubia, M., Robledo, D.1, Freile-Pelegrin, Y. Antioxidant activities in tropical marine macroalgae from the Yucatan Peninsula, Mexico. J Appl Phycol. 2007, 19, $449-458$

15. Mittler R Oxidative stress, antioxidants and stress tolerance. Trends Plant Sci. 2002,7, 405-410.

16. Yuan, Y. V.; Carrington, M. F.; Walsh, N. A. Extracts from dulse (Palmaria palmata) are effective antioxidants and inhibitors of cell proliferation in vitro. Food Chem Toxicol. 2005,43,1073-1081.

17. Yoshie, Y.; Wang, W.; Hsieh, Y. P.; Suzuki, T. Compositional difference of phenolic compounds between two seaweeds, Halimeda spp. J. Tokyo Univ. Fish. 2002,88, 21-24.

18. Xu WH.; Ding Y.; Jacob MR.; Agarwal AK.; Clark AM.; Ferreira D.; Liang ZS, Li XC. Puupehanol, a sesquiterpenehydroquinone derivative from the marine sponge Hyrtios sp. Bioorg. Med. Chem. Lett. 2009,19, 6140-6143.

19. Thomas TRA.; Kaulekar DP.; Lokabarathi PA. Marine drugs from spongemicrobe association: a review. Mar. Drugs. 2010,8,1417-1468.

20. Zhao, M. Yang, B. Wang, J. Liu, Y. Yu, L. and Jiang, Y. "Immunomodulatory and anticancer activities of flavonoids extracted from litchi (Litchi chinensis Sonn.) pericarp. Int Immunopharmacol. 2007, 7,162- 166.

21. Gawron, A.; Kruk, I. Cytotoxic effect of xanthotoxol (8-hydroxypsoralen) on TCTC cells in vitro, Pol J Pharmacol Pharm. 1992,44,51-57.

22. Duan, X.; Wu, G.; Jiang, Y. "Evaluation of the antioxidant properties of litchi fruit phenolics in relation to pericarp browning prevention. Molecules, 2007,12, 759771. 
23. Wang, B. G.; Zhang,W. W; Duan, X. J.; Li, X. M. In vitro antioxidative activities of extract and semi-purified fractions of the marine red alga, Rhodomela confervoides (Rhodomelaceae). Food Chem. 2009,113,1101- 1105.

24. Vasanthi HR, Rajamanickam GV, Saraswathy A. Tumoricidal effect of the red algae Acanthophora spicifera on Ehrlich's ascites carcinoma in mice, Seaweed Res. UtilNet 2004, 25,217-224.

25. Heo, S. J.; Park,P. J.; Park, E. J.; Kim, SE. K.; Jeon, Y. J. Antioxidant activity of enzymatic extracts from a brown seaweed Ecklonia cava by electron spin resonance spectrometry and comet assay. Eur Food Res Technol. 2005, 221, 41-47.

26. Athukorala, Y.; Jung, W.K.; Vasanthan, T.; Jeon, Y.J. An anticoagulative polysaccharide from an enzymatic hydrolysate of Ecklonia cava, Carbohyd Polym, 2006, 66,184-191.

27. Senevirathne, M S.; Kim, N.; Siriwardhana, J. Ha, K. Lee Y. Jeon, Antioxidant potential of Ecklonia cava on reactive oxygen species scavenging, metal chelating, reducing power and lipid peroxidation inhibition. Food Sci. Technol. Int. 2006;12: $27-38$.

28. Marinova, D.; Ribarova, F.; Atanassova, M. Total phenolics and total flavonoids in Bulgarian fruits and vegetables. J Chem Technol Biot 2005,40, 255-260.

29. Park Y-S.; Jung S-T.; Kang S-G.; Heo BK.; Arancibia-Avila P.; Toledo F.; Drzewiecki J.; Namiesnik J.; Gorinstein S. Antioxidants and proteins in ethylenetreated kiwifruits. Food Chem. 2008, 107, 640-648.

30. Dandlen, S.A.; Lima, A.S.; Mendes, M.D.; Miguel, M.G.; Faleiro, M.L.; Sousa, M.J.; Pedro, L.G.; Barroso, J.G.; Figueiredo, A.C. Antioxidant activity of six Portuguese thyme species essential oils. Flavour Fragr. J., 2010, 25, 150-155.

31. Oyaizu, M. Studies on product of browning reaction prepared from glucose amine. Jpn J Nutr. 1986, 44, 307-315.

32. Denkert C.; Furstenberg A.; Daniel PT.; Koch I.; Kobel M.; Weichert W.; Siegert A. Hauptmann S. Induction of G0/G1 cell cycle arrest in ovarian carcinoma cells by the anti-inflammatory drug NS-398, but not by COX-2-specific RNA interference. Oncogene 2003, 22, 8653-8661. 
33. Sheih, C.; Fang, T.; Wu, T.; Lin, P. Anticancer and Antioxidant Activities of the Peptide Fraction from Algae Protein Waste. J. Agric. Food Chem. 2010, 58, $1202-$ 1207.

34. Sanja SD.; Sheth NR.; Patel NK.; Dhaval Patel.; Biraju Patel. Characterization and evaluation of antioxidant activity of Portulaca oleracea. Intl $\mathrm{J}$ pharma pharma sci 2009, 1, 74-84.

35. Indu.h.; Seenivasan, R. In vitro antioxidant activity of selected seaweeds from southeast coast of India.. Int J Pharm Pharm Sci. 2013,474-484.

36. Ksouri R.; Megdiche W.; Falleh H.; Trabelsi N.; Boulaaba M.; Smaoui A.; Abdelly C. Influence of biological, environmental and technical factors on phenolic content and antioxidant activities of Tunisian halophytes. C. R. Biol. 2008,331,865873.

37. Moghadamtousi, S.; Karimian, H.; Khanabdali, R.; Razavi, M.; Firoozinia, M.; Zandi, K.; Abdul Kadir, H. Anticancer and antitumor potential of fucoidan and fucoxanthin, two main metabolites isolated from brown algae. The scientific world $\mathbf{J}$ 2014, 2014,1-10.

38. Karthick, N.; Anees Fathimal, M.; Ramesh, K.; Sridhar, H.; Natrajan, M.; Divya, VV.; Umavanitha, M.; Umamaheswari, S. Screening of phytochemicals and antimicrobial activity of Caulerpa scalpelliformis collected from Manapad Coast, Tuticorin District, Tamilnadu, South India. J. coast. life med.. 2014, 2, 107-111

39. Salucci, M . A.; Stivala, L.; Maiani, G.; Bugianesi, R .; Vannini, V . Flavonoids uptake and their effect on cell cycle of human colon adenocarcinoma cells (Caco2). Br J Cancer. 2002, 86, 1645-1651.

40. Du,G.; Lin,H. M.; Wang, M.; Zhang S.; Wu X.; Lu L.; Ji L.; Yu L. Quercetin greatly improved therapeutic index of doxorubicin against 4T1 breast cancer by its opposing effects on HIF-1 $\alpha$ in tumor and normal cells. Can J Physiol Pharm. 2010,65, 277-287.

41. Plochmann, K.; Korte, G.; Koutsilieri, E.; Richling, P.; Rethwilm, A.; Schreier, P.; Schelle, C. Structure-activity relationships of flavonoid-induced cytotoxicity on human leukemia cells. Arch Biochem Biophys. 2007,460, 1-9.

42. Kuttan G.; Kumar KB.; Guruvayoorappan C.; Kuttan R. Antitumor, anti-invasion, and antimetastatic effects of curcumin. Adv Exp Med Biol. 2007, 595,173-184.

43. Lamoral-Theys D.; Pottier L.; Dufrasne F.; Neve J.; Dubois J.; Kornienko A.; Kiss R.; Ingrassia L.; Lamoral-Theys D.; Pottier L.; Dufrasne F.; Neve J.; Dubois J.; 
Kornienko A.; Kiss R.; Ingrassia L. Natural polyphenols that display anticancer properties through inhibition of kinase activity. Curr Med Chem. 2010, 17(814), 812825.

44. Minko, T.; Dharap, S. S.; Fabbricatore, A. T. Enhancing the efficacy of chemotherapeutic drugs by the suppression of antiapoptosis cellular defense. Cancer Detect. Prev. 2003, 27, 193-202

45. Palozza, P.; Torelli, C.; Boninsegna, A. et al., Growth-inhibitory effects of the astaxanthin-rich alga Haematococcus pluvialis in human colon cancer cells. Cancer Lett. 2009, 283, 108-117.

46. Moungjaroen J.; Nimmannit U.; Callery PS.; Wang L.; Azad N.; Lipipun V.; Chanvorachote P.; Rojanasakul Y. Reactive oxygen species mediate caspase activation and apoptosis induced by lipoic acid in human lung epithelial cancer cells through Bcl-2 downregulation. J Pharmacol Exp Ther. 2006,319,1062-1069.

47. McCullagh, M. Natural product pharmaceuticals-the third generation. Drug Disc. World 2008.

(C) 2016 by the authors; licensee Preprints, Basel, Switzerland. This article is an open access article distributed under the terms and conditions of the Creative Commons by Attribution (CC-BY) license (http://creativecommons.org/licenses/by/4.0/). 